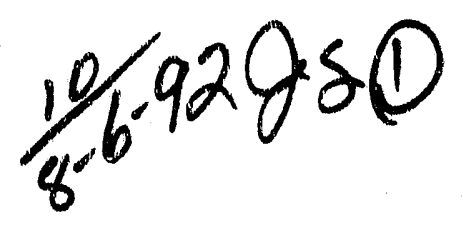

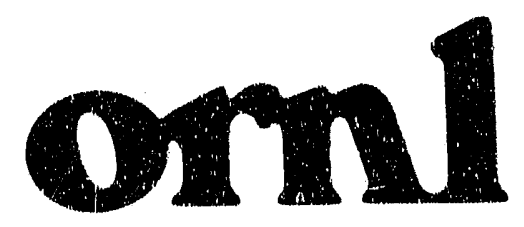

OAK RIDGE

NATIONAL

LABORATORY

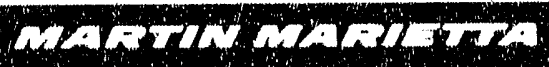

\section{Treatability Studies for Decontamination of Melton Valley Storage Tank Supernate}

\author{
W. D. Arnold \\ V. L. Fowler \\ J. J. Perona \\ D. R. McTaggant
}


This report has boen reproducud directly from the best available copy.

Available to DOE and DOE contractors from the Otfice of Scientific and Technical Information, P.O Box 62. Dek Ridge, TN 37831; prices available from (615) 576-8401, FTS 626-8401

Available to the public from the National Technical Intormation Service, U.S. Department of Commerce, 5285 Port Royal Rd, Springtield, VA 22161.

This report was prepared as an account of work sponsored by an agency of the United States Government. Neither the United States Government nor any agency thereot, nor any of their employees, makes any warranty, express or implied, or aseurnes any legal liability or responsibility for the accuracy, com. pleteness, or usefulness of any information, apparatus, product, or process disclosed, or fopresents that its use would not infringe privately owned rights. Reference herein to any specific commercial product, process, or service by trade name, trademark, manufacturer, or otherwise, does not necessarily constitute or imply it endorsernent, recommendation, of favoring by the United States Government or any agency theroof. The views and opinions of authors expressed herein do not necessarily state or reflect those of the United States Governinent or any agency thereof. 
ORNL/TM--12031.

DE92 018097

TREATABILITY STUDIES FOR DECONTAMINATION OF MELTON VALLEY STORAGE TANK SUPERNATE

W. D. Fsrnold

V. L. Fowler

J. J. Perona

D. R. McTaggart

Chemical Technology Division

Oak Ridge National Laboratory

Oak Ridge, Tennessee 37831-6044

August 1992

Prepared by

OAK RIDGE NATIONAL LABORATORY

Oak Ridge, Tennessee 37831

managed by

MARTIN MARIETTA ENERGY SYSTEMS, INC.

for the

U.S. DEPARTMENT OF ENERGY

under contract DE-AC05-84OR21400 


\section{CONTENTS}

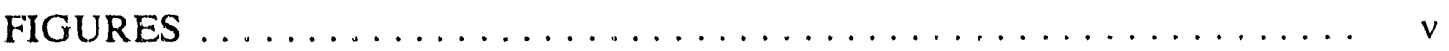

TAøLES $\ldots \ldots \ldots \ldots \ldots \ldots \ldots \ldots \ldots \ldots \ldots \ldots \ldots \ldots \ldots \ldots \ldots \ldots \ldots$

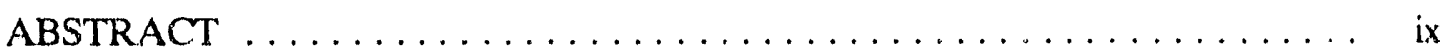

1. INTRODUCTION $\ldots \ldots \ldots \ldots \ldots \ldots \ldots \ldots \ldots \ldots \ldots \ldots \ldots$

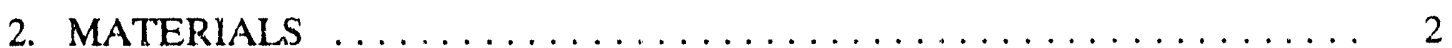

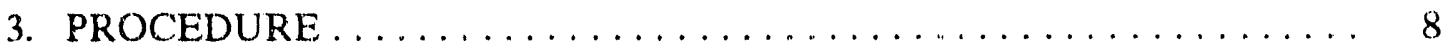

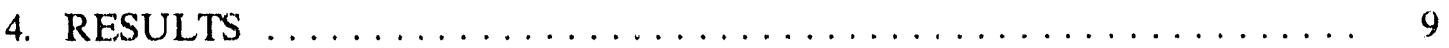

5. CONCLUSIONS AND RECOMMENDATIONS $\ldots \ldots \ldots \ldots \ldots \ldots \ldots .6$

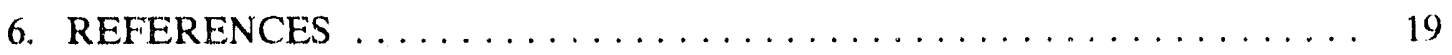




\section{FIGURES}

1. Titration of simulated supernate samples $\ldots \ldots \ldots \ldots \ldots \ldots \ldots$

2. Effects of KCCF source and supernate composition on cesium decontamination . . . . . . . . . . . . . . . . . 10

3. Effect of mixing time on cesium decontamination $\ldots \ldots \ldots \ldots \ldots \ldots \ldots$

4. Effect of settling time on cesium decontamination $\ldots \ldots \ldots \ldots \ldots \ldots$

5. Effect of sample location on cesium decontamination $\ldots \ldots \ldots \ldots \ldots \ldots$ 


\section{TABLES}

1. Decontamination requirements for MVST supernate radionuclides to meet proposed Class L-II waste acceptance criteria

2. Composition of simulated supernates $\ldots \ldots \ldots \ldots \ldots \ldots \ldots \ldots \ldots \ldots$

3. Acid requirements to adjust simulated supernate $\mathrm{pH} \ldots \ldots \ldots \ldots \ldots$

4. Results of settling tests . . . . . . . . . . . . . . . . . . . . . . . 16 


\section{ABSTRACT}

Liquid low-level waste, primarily nitric acid contaminated with radionuclides and minor concentrations of organics and heavy metals, is neutralized with sodium hydroxide, concentrated by evaporation, and stored for processing and disposal. The evaporator concentrate separates into sludge and supernate phases upon cooling. The supernate is 4 to $5 \mathrm{~mol} / \mathrm{L}$ sodium nitrate contaminated with soluble radionuclides, principally ${ }^{137} \mathrm{Cs}{ }^{90} \mathrm{Sr}$, and ${ }^{14} \mathrm{C}$, while the sludge consists of precipitated carbonates and hydroxides of metals and transuranic elements. Methods for treatment and disposial of this waste are being developed.

In studies to determine the feasibility of removing ${ }^{137} \mathrm{Cs}$ from the supernates before solidification campaigns, batch sorption measurements were made from four simulated supernate solutions with four different samples of potassium hexacyanocobalt ferrate (KCCF). Cesium decontamination factors of 1 to 8 were obtained with different KCCF batches from a highly-salted supernate at $\mathrm{pH} 13$. Decontamination factors as high as 50 were measured from supernates with lower salt content and $\mathrm{pH}$, in fact, the $\mathrm{pH}$ had a greater effect than the solution composition on the decontamination factors. The decontamination factors were highest after 1 to $2 \mathrm{~d}$ of mixing and decreased with longer mixing times due to decomposition of the KCCF in the alkaline solution. The decontamination factors decreased with settling time and were lower for the same total contact time (mixing + settling) for the longer mixing times, indicating more rapid KCCF decomposition during mixing than during settling. There was no stratification of cesium in the tubes as the $\mathrm{KCCF}$ decomposed. Settling tests with particle size fractions averaging 273 and 774 $\mu \mathrm{m}$ resulted in a Reynolds number range of 1.4 to 36 in water and simulated supernate. These experimental settling velocities were used to estimate an effective particle density of $1.49 \mathrm{~g} / \mathrm{cm}^{3}$, which includes liquid in the particle void space and is significantly lower than the true density of about $2.3 \mathrm{~g} / \mathrm{cm}^{3}$.

These results indicate that in-tank treatment to remove cesium from the supernates is not feasible. The supernates could possibly be decontaminated by removing them from the tanks and treating them under more controlled conditions than is possible in the tanks. Treatment would include $\mathrm{pH}$ adjustment to an optimum range and batch treatment with KCCF to remove cesium, followed by separation of solids from the solution and disposal of the treated liquid and the solids. Additional development work is needed before this could be done. Treatment methods to remove ${ }^{14} \mathrm{C}$ from the supernates are also needed. 


\begin{abstract}
Liquid low-level waste, primarily nitric acid contaminated with radionuclides and minor concentrations of organics and heavy metals, is neutralized with sodium hydroxide, concentrated by evaporation, and stored for processing and disposal. The evaporator concentrate separates into sludge and supernate phases upon cooling. The supernate is 4 to $5 \mathrm{~mol} / \mathrm{L}$ sodium nitrate contaminated with soluble radionuclides, principally ${ }^{137} \mathrm{Cs},{ }^{90} \mathrm{Sr}$, and ${ }^{14} \mathrm{C}$, while the sludge consists of precipitated carbonates and hydroxides of metals and transuranic elements. Methods for treatment and disposal of this waste are being developed.
\end{abstract}

In studies to determine the feasibility of removing ${ }^{137} \mathrm{Cs}$ from the supernates before solidification campaigns, batch sorption measurements were made from four simulated supernate solutions with four different samples of potassium hexacyanocobalt ferrate (KCCF). Cesium decontamination factors of 1 to 8 were obtained with different KCCF batches from a highly-salted supernate at $\mathrm{pH}$ 13. Decontamination factors as high as 50 were measured from supernates with lower salt content and $\mathrm{pH}$, in fact, the $\mathrm{pH}$ had a greater effect than the solution composition on the decontamination factors. The decontamination factors were highest after 1 to $2 \mathrm{~d}$ of mixing and decreased with longer mixing times due to decomposition of the $\mathrm{KCCF}$ in the alkaline solution. The decontamination factors decreased with settling time and were lower for the same total contact time (mixing + settling) for the longer mixing times, indicating more rapid $\mathrm{KCCF}$ decomposition during mixing than during settling. There was no stratification of cesium in the tubes as the KCCF decomposed. Settling tests with particle size fractions averaging 273 and 774 $\mu \mathrm{m}$ resulted in a Reynolds number range of 1.4 to 36 in water and simulated supernate. These experimental settling velocities were used to estimate an effective particle density of $1.49 \mathrm{~g} / \mathrm{cm}^{3}$, which includes liquid in the particle void space and is significantly lower than the true density of about $2.3 \mathrm{~g} / \mathrm{cm}^{3}$.

These results indicate that in-tank treatment to remove cesium from the supernates is not feasible. The supernates could possibly be decontaminated by removing them from the tanks and treating them under more controlled conditions than is possible in the tanks. Treatment would include $\mathrm{pH}$ adjustment to an optimum range and batch treatment with $\mathrm{KCCF}$ to remove cesium, foliowed by separation of solids from the solution and disposal of the treated liquid and the solids. Additional development work is needed before this could be done. Treatment methods to remove ${ }^{14} \mathrm{C}$ from the supernates are also needed. 


\title{
TREATABILITY STUDIES FOR DECONTAMINATION OF MELTON VALLEY STORAGE TANK SUPERNATE
}

\author{
W. D. Arnold, V. L. Fowler, J. J. Perona, D. R. McTaggart
}

\section{INTRODUCTION}

Liquid low-level waste (LLLW), primarily nitric acid contaminated with radionuclides and minor concentrations of organics and heavy metals, is collected in tanks, neutralized with sodium hydroxide, concentrated by evaporation, and stored for processing and disposal. Upon cooling, the LLLW concentrate (LLLWC) separates into sludge and supernate phases. The supernate is $4-5 \mathrm{~mol} / \mathrm{L}$ sodium nitrate contaminated with soluble radionuclides, primarily ${ }^{137} \mathrm{Cs}$, ${ }^{90} \mathrm{Sr}$, and ${ }^{14} \mathrm{C}$, while the sludge consists of precipitated carbonates and hydroxides of metal and transuranic elements. Since the discontinuance of hydrofracture in 1984, LLLWC has been accumulating in the Melton Valley Storage Tanks (MVST). Limited storage capacity is available for this waste, and methods for treating and disposing of this waste are being developed.

A Waste Handling and Packaging Plant (WHPP) has been proposed as a FY 1994 line item project to process and solidify this waste for shipment to the Waste Isolation Pilot Plant in Carlsbad, New Mexico. ${ }^{1}$ Initial results of scoping studies to determine potential processes for removing cesium and strontium from the MVST supernate for inclusion in the WHPp facility indicated that hexacyanoferrate ion exchangers and sodium titanate ion exchangers could result in decontamination factors of $10^{4}$ for cesium and $10^{3}$ for strontium, respectively. ${ }^{2}$

The supernates will either be solidified in concrete or concentrated by in-tank evaporation to provide additional storage space until the WHPP becomes operational. ${ }^{3}$ A solidification campaign was performed in 1988 in which 50,000 gal of supernate in tanks W-29 
and W-30 were solidified, ${ }^{4}$ and similar campaigns are planned for FY 1992 and 1993 . The radionuclides in the supernates in these tanks ${ }^{5}$ are listed in Table 1 along with the applicable preliminary waste acceptance criteria (WAC) for the centralized Class L-II solid waste disposal facility (based on the pathways analyses performed in October 1990). ${ }^{6}$ The decontamination factors required to meet these Class L-II WAC are also listed in Table 1, assuming that the waste volume increases $50 \%$ during solidification. The results indicate that decontamination factors of $\sim 15$ for ${ }^{137} \mathrm{Cs}$ and $\sim 8$ for ${ }^{14} \mathrm{C}$ will be requirec to meet the Class L-II WAC.

This study was initiated to determine if ${ }^{137} \mathrm{Cs}$ could easily be removed from MVST supernate using potassium cobalt hexacyanoferrate (KCCF) ion exchanger prior to near-term solidification campaigns to avoid production of Class L-IV waste forms, which have no presently approved disposal method. A secondary objective was to obtain additional data needed for the WHPP design. The research focused on the feasibility of adding KCCF to the MVST for in situ decontamination. Scoping studies were performed to determine the effects of the KCCF production process, KCCF particle size, supernate composition, supernate $\mathrm{pH}$, tank mixing rates, particle settling rates, and liltration methods on in situ decontamination. These studies are described below."

\section{MATERIALS}

Sorption measurements were made from four simulated supernate solutions that had the compositions shown in Table 2. The High-Salt supernate, which represented a "worst case" in that it had a higher concentration of soluble salts than measured in any of the storage

*The original data for the tests described in this report are recorded in ORNL lab notebooks A-103962-G and 104244-G. 
Table 1. Decontamination requirements for MVST supernate radionuclides to meet proposed Class L-II waste acceptance crileria

\begin{tabular}{lccccc}
\hline \multirow{2}{*}{ Radionuclide } & \multicolumn{2}{c}{$\begin{array}{c}\text { Concentration in supernate } \\
\left(\mu \mathrm{Ci} / \mathrm{m}^{3}\right)\end{array}$} & $\begin{array}{c}\text { WAC } \\
\left(\mu \mathrm{Ci} / \mathrm{m}^{3}\right)\end{array}$ & \multicolumn{2}{c}{$\begin{array}{c}\text { Decontamination } \\
\text { factors }\end{array}$} \\
\cline { 2 - 3 } & $\mathrm{W}-29$ & $\mathrm{~W}-30$ & & W-29 & W-30 \\
\hline Gross alpha & $2.70 \times 10^{1}$ & $2.70 \times 10^{1}$ & $1.04 \times 10^{6}$ & 0 & 0 \\
${ }^{14} \mathrm{C}$ & $2.45 \times 10^{3}$ & $2.38 \times 10^{3}$ & $2.01 \times 10^{2}$ & 8 & 8 \\
${ }^{60} \mathrm{Co}$ & $1.68 \times 10^{4}$ & $1.32 \times 10^{4}$ & $1.02 \times 10^{12}$ & 0 & 0 \\
${ }^{137} \mathrm{Cs}$ & $5.94 \times 10^{6}$ & $5.07 \times 10^{6}$ & $2.53 \times 10^{5}$ & 16 & 13 \\
${ }^{90} \mathrm{Sr}$ & $1.90 \times 10^{5}$ & $1.82 \times 10^{5}$ & $8.88 \times 10^{5}$ & 0 & 0 \\
\hline
\end{tabular}

"WAC = waste acceptance criteria proposed for Class L-II.

becontamination factors assume a $50 \%$ volume increase during solidification of waste. 
Table 2. Composition of simulated supernates

\begin{tabular}{lcccc}
\hline & \multicolumn{4}{c}{ Concentration $(\mathrm{mol} / \mathrm{L})$} \\
\cline { 2 - 5 } Component & High-Salt & Tank 29 & $\mathrm{NaNO}_{3}$-I & $\mathrm{NaNO}_{3}$-II \\
\hline $\mathrm{NaNO}_{3}$ & 5.98 & 3.90 & 3.90 & 3.90 \\
$\mathrm{NaOH}$ & 0.01 & 0.24 & 0.65 & 0.002 \\
$\mathrm{Na}_{2} \mathrm{CO}_{3}$ & 0.20 & 0.14 & $\mathrm{NP}^{\mathrm{a}}$ & $\mathrm{NP}$ \\
& & & & \\
$\mathrm{NaCl}$ & 0.08 & 0.10 & $\mathrm{NP}$ & $\mathrm{NP}$ \\
$\mathrm{KNO}_{3}$ & 1.37 & 0.24 & $\mathrm{NP}$ & $\mathrm{NP}$ \\
$\mathrm{CaCO}$ & $\mathrm{NP}$ & 0.0001 & $\mathrm{NP}$ & $\mathrm{NP}$ \\
$\mathrm{Ca}\left(\mathrm{OH}_{2}\right)_{2}$ & 0.19 & $\mathrm{NP}$ & $\mathrm{NP}$ & $\mathrm{NP}$ \\
$\mathrm{Mg}(\mathrm{OH})_{2}$ & 0.07 & $\mathrm{NP}$ & $\mathrm{NP}$ & $\mathrm{NP}$ \\
$\mathrm{Al}\left(\mathrm{NO}_{3}\right)_{3}$ & $\mathrm{NP}$ & 0.005 & $\mathrm{NP}$ & $\mathrm{NP}$ \\
$\mathrm{Zn}\left(\mathrm{NO}_{3}\right)_{2}$ & $\mathrm{NP}$ & 0.001 & $\mathrm{NP}$ & $\mathrm{NP}$ \\
$\mathrm{pH}$ & 13.1 & 12.7 & 13.1 & 10.7 \\
$\mathrm{Density}(\mathrm{g} / \mathrm{mL})$ & 1.376 & 1.242 & 1.223 & 1.196 \\
\hline
\end{tabular}

${ }^{a} \mathrm{NP}=$ Not present. 
tanks, ${ }^{5}$ contained about $6.5 \mathrm{~mol} / \mathrm{L}$ sodium and $1.4 \mathrm{~mol} / \mathrm{L}$ potassium. The $\mathrm{pH}$ of the solution was measured at 13.0. The composition of the simulated Tank 29 supernate closely approximates that of the actual supernate in Melton Valley Storage Tank W-29. 5 This solution contained about $4.5 \mathrm{~mol} / \mathrm{L}$ sodium and $0.25 \mathrm{~mol} / \mathrm{L}$ potassium at $\mathrm{pH}$ 12.7. Comparative tests were made with $3.9 \mathrm{~mol} / \mathrm{L}$ sodium nitrate $\left(\mathrm{NaNO}_{3}\right)$ solutions adjusted to $\mathrm{pH} 13.0\left(\mathrm{NaNO}_{3}-\mathrm{I}\right)$ or to $10.7\left(\mathrm{NaNO}_{3}-\mathrm{II}\right)$ with sodium hydroxide $(\mathrm{NaOH})$. These solutions were included $t C$ determine the effect of potassium on cesium decontamination with KCCF. The potassium concentration of the MVST supernates varies over a wide range, ${ }^{5}$ and it is possible that potassium could be eliminated from LLLW streams generated in the future. The measured densities of the solutions were $1.376 \mathrm{~g} / \mathrm{mL}$ for the High-Salt supernate, 1.242 $\mathrm{g} / \mathrm{mL}$ for the Tank W-29 supernate, $1.223 \mathrm{~g} / \mathrm{mL}$ for the $\mathrm{pH} 13.0 \mathrm{NaNO}_{3}$ solution, and 1.196 $\mathrm{g} / \mathrm{mL}$ for the $\mathrm{pH} 10.7 \mathrm{NaNO}_{3}$ solution. The cesium concentration of the solutions was adjusted with cesium chloride $(\mathrm{CsCl})$ to $0.069 \mathrm{mg} /$, which is equivalent to the ${ }^{137} \mathrm{Cs}$ concentration of $2.2 \times 10^{5} \mathrm{~Bq} / \mathrm{L}$ reported for Tank W-29, ${ }^{5}$ and then the solutions were traced with ${ }^{137} \mathrm{Cs}$.

Samples of the High-Salt and the Tank 29 simulated supernates were litrated with $\mathrm{HCl}$ to determine the acid needed for $\mathrm{pH}$ adjustment (Fig. 1 and Table 3). The High-Salt supernate required about $50 \%$ more acid for adjustment to pH 11 , about $35 \%$ more for adjustment to $\mathrm{pH} 10$, and about $10 \%$ more for adjustment to pH 9 . A small amount of white solid precipitated from the Tank 29 supernate in the $\mathrm{pH}$ range of 11 to 9 . The precipitate redissolved in the pH range of 5 to 4 .

Four samples of potassium cobalt hexacyanoferrate were tested. Samplos A and B were obtained from chemical suppliers (sample B is no longer available and was used only in a few comparative tests), and samples $C$ and D were prepared at ORNL. The ORNL samples were 


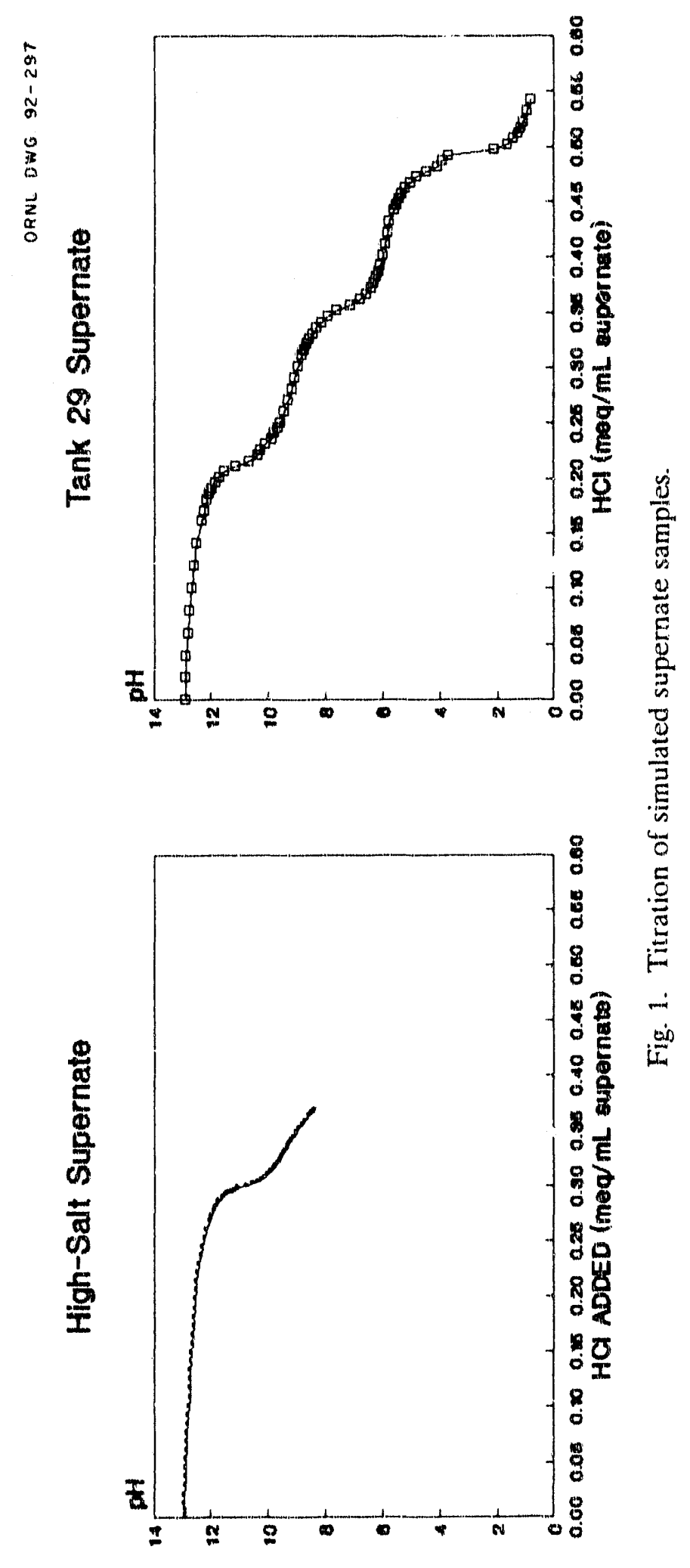


Table 3. Acid requirements to adjust simulated supernate $\mathrm{pH}^{\mathbf{2}}$

\begin{tabular}{ccc}
\hline Simulated supernate & $\mathrm{pH}$ & Volume $\mathrm{HCl}(\mathrm{gal})$ \\
\hline High-Salt & 13.1 & - \\
& 11.0 & 25.0 \\
& 10.0 & 26.7 \\
& 9.0 & 29.2 \\
Tank 29 & & \\
& 12.7 & - \\
& 11.0 & 16.7 \\
& 10.0 & 19.2 \\
& 9.0 & 26.7 \\
\hline
\end{tabular}

'Basis: 1000 gal supernate. 
prepared by the method of Prout, Russell, and Groh. ${ }^{8}$ This method was also used to prepare the KCCF used in earlier ORNL studies.' Electron-excited energy dispersive X-ray fluorescence analyses indicated that the four KCCF samples have the same elemental composition, and $\mathrm{X}$-ray diffraction (XRD) analyses also indicated that the compounds are identical. However, the XRD analyses also demonstrated that samples $\mathrm{A}$ and $\mathrm{D}$ are more crystalline, which suggests that samples $B$ and $C$ are more finely-divided. The granular KCCF samples were in the size range of 20 to 50 mesh $(840$ to $297 \mu \mathrm{m})$. The particles broke into much smaller pieces as soon as they came in contact with the strongly alkaline simulated supernate solutions, but this separation did not occur with the $\mathrm{NaNO}_{3}$ solution at the lower $\mathrm{pH}\left(\mathrm{NaNO}_{3}-\mathrm{II}\right)$

\section{PROCEDURE}

Cesium sorption tests were performed using the batch equilibration method. For these tests, weighed amounts of granular KCCF samples were added to preweighed screw-cap centrifuge tubes. Simulated supernate solutions were added to the tubes and the tubes were weighed again. The solution volume was determined by the weight and density of the solutions. The solution/solid ratio was $1000 / 1$ and three samples were included for each data set in most of the tests. The solids and solutions were mixed by gently rocking at 20 cycles per minute between $+45^{\circ}$ and $-45^{\circ}$ from horizontal. The tubes were usually weighed again at the end of the mixing period to determine any solution loss. To simulate possible usage in the storage tanks, the solids were allowed to settle for a measured time before aliquots were removed for counting. In some of the tests, the samples were returned to the tubes after counting, and mixing with the KCCF was continued. This was not done with samples that were centrifuged or filtered. Centrifugation was usually for 30 min at 5000 relative 
centrifugal force (rcf), and filtration was through $0.20-\mu \mathrm{m}$ membranes. Cesium removal was measured by counting the ${ }^{137} \mathrm{Cs}$ in the treated solutions and comparing the count rate with that of the untreated supernate. The results were calculated as the $D F, D F=C_{i} / C_{i}$, where $C_{i}$ is the initial count rate and $C_{f}$ is the final count rate.

\section{RESULTS}

The cesium DFs were affected by the solution $\mathrm{pH}$ and composition as well as by the source of the KCCF. Figure 2 shows the average DFs obtained with the different KCCFsolution combinations after a mixing time of $1 \mathrm{~d}$. The samples were clarified before sampling by settling for $1.5 \mathrm{~h}$ in the case of the High-Salt and Tank 29 supernates and by centrifuging $30 \mathrm{~min}$ of $5000 \mathrm{rcf}$ in the case of the $\mathrm{NaNO}_{3}$ solutions. Other results showed that DFs are slightly higher in centrifuged samples than in settled samples after $1 \mathrm{~d}$ of mixing. Each KCCF sample behaved differently. The commercially available KCCF sample $A$ was almost completely ineffective with all except the $\mathrm{pH} 10.7 \mathrm{NaNO}_{3}$ solution, where a DF of 23 was measured. KCCF sample $\mathrm{B}$ had DFs of about 11 from the $\mathrm{pH} 13.0 \mathrm{NaNO}_{3}$ solution and about 55 from the $\mathrm{pH} 10.3 \mathrm{NaNO}_{3}$ solution. These compare to DFs of 9 and 27.6 with $\mathrm{KCCF}$ sample $\mathrm{C}$ and 3.7 and 17.6 with KCCF sample D from the same solutions. Although samples $C$ and $D$ were prepared by the same method, DFs from all four supernates were lower with sample D than with sample C. With both KCCF samples, the DFs were highest from the Tank 2.9 supernate and lowest from the High-Salt supernate. The results with the $\mathrm{pH}$ 13.0 $\mathrm{NaNO}_{3}$ solution were closer to those with the High-Salt solution than to those with Tank 29 solution, which indicates that the $\mathrm{pH}$ has a greater effect than the solution composition (i.e., the cations present and their concentrations) on the DF. 


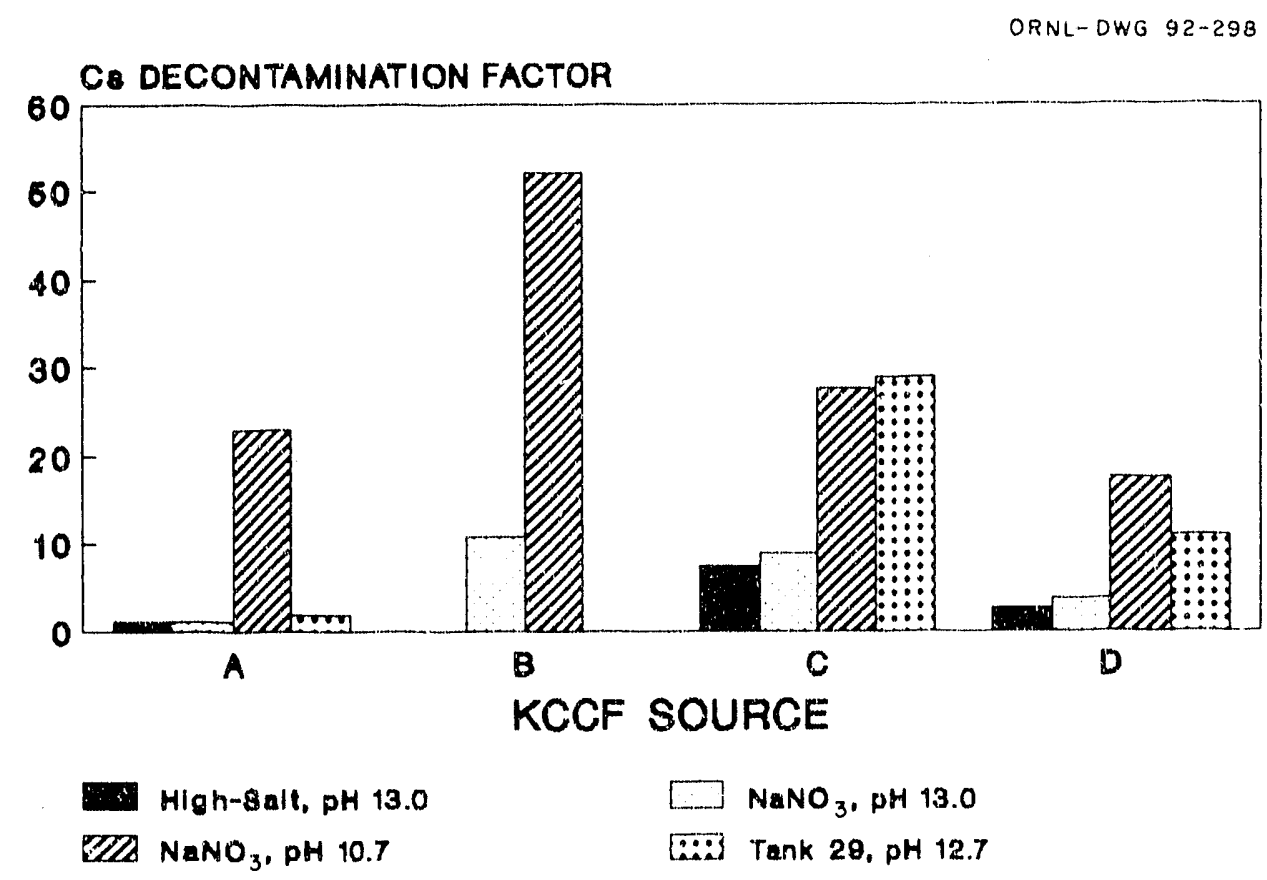

Figure 2. Effects of KCCF source and supernate composition on cesium decontamination. 
To determine the effect of mixing time on cesium decontamination, simulated Tank 29 supernate was mixed with KCCF sample $\mathcal{C}$ for up to $14 \mathrm{~d}$. Aliquots of the supernate for each mixing time were measured for cesium content after $1.5 \mathrm{~h}$ settling, after $30 \mathrm{~min}$ centrifugation at $5000 \mathrm{rcf}$, and after filtration through a $0.2-\mu \mathrm{m}$ membrane. The DFs reached a maximum after 1 to $2 \mathrm{~d}$ mixing and then decreased with longer mixing times (Fig. 3). The DF values were only slightly higher for the centrifuged or filtered samples than for the settled samples for up to $6 \mathrm{~d}$ of mixing, which indicates that settling might provide adequate phase separation. There was no difference between the settled, centrifuged, or filtered samples after $6 \mathrm{~d}$ or more mixing. These results show that the KCCF is effective for only a limited time when it is in contact with highly alkaline solutions and that the optimum mixing time appears to be about $1 \mathrm{~d}$. The decrease in the DFs for longer mixing times is possibly due to decomposition of the KCCF as a result of extended contact with the highly alkaline solution. These results are consistent with those of other studies that showed KCCF is stable for longer times at lower pH levels. ${ }^{7}$ The cesium content of the samples from the mixing tests described in Fig. 3 was measured periodically over extended settling times to determine the DFs as a function of bo:h mixing and settling times. The results (Fig. 4) show again that the optimum mixing time ranges from $6 \mathrm{~h}$ to $1 \mathrm{~d}$. For both mixing times, the DFs continued to increase for settling periods of up to $3 \mathrm{~d}$ after the mixing stopped and then began to decrease. For the longer mixing times, the DFs always decreased with longer settling times and were lower for the same total contact time (mixing + settling) for the longer mixing times. After the samples were mixed for a few days, they acquired a yellow color that intensified with increasing mixing time. The inside surface of the sample tubes that were mixed for longer times became coated with tan slimy precipitate, suggesting that decomposition of the KCCF is more rapid during mixing than during settling. These results reemphasize that the KCCF treatment remains effective for cesium removal from highly alkaline solutions only for a limited time. 
ORNI - DWG $92-239$

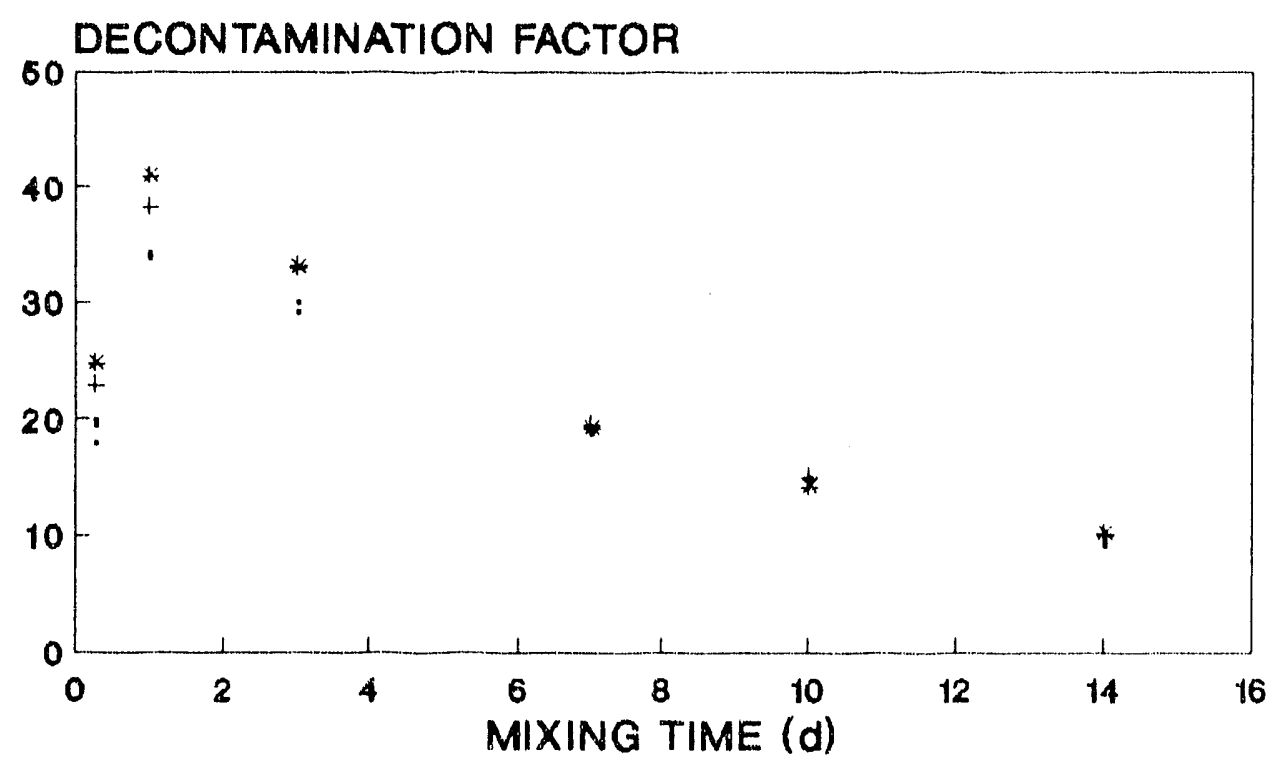

- Settlod + Contrifuged * Filtered

Fig. 3. Effect of mixing time on cesium decontamination. 

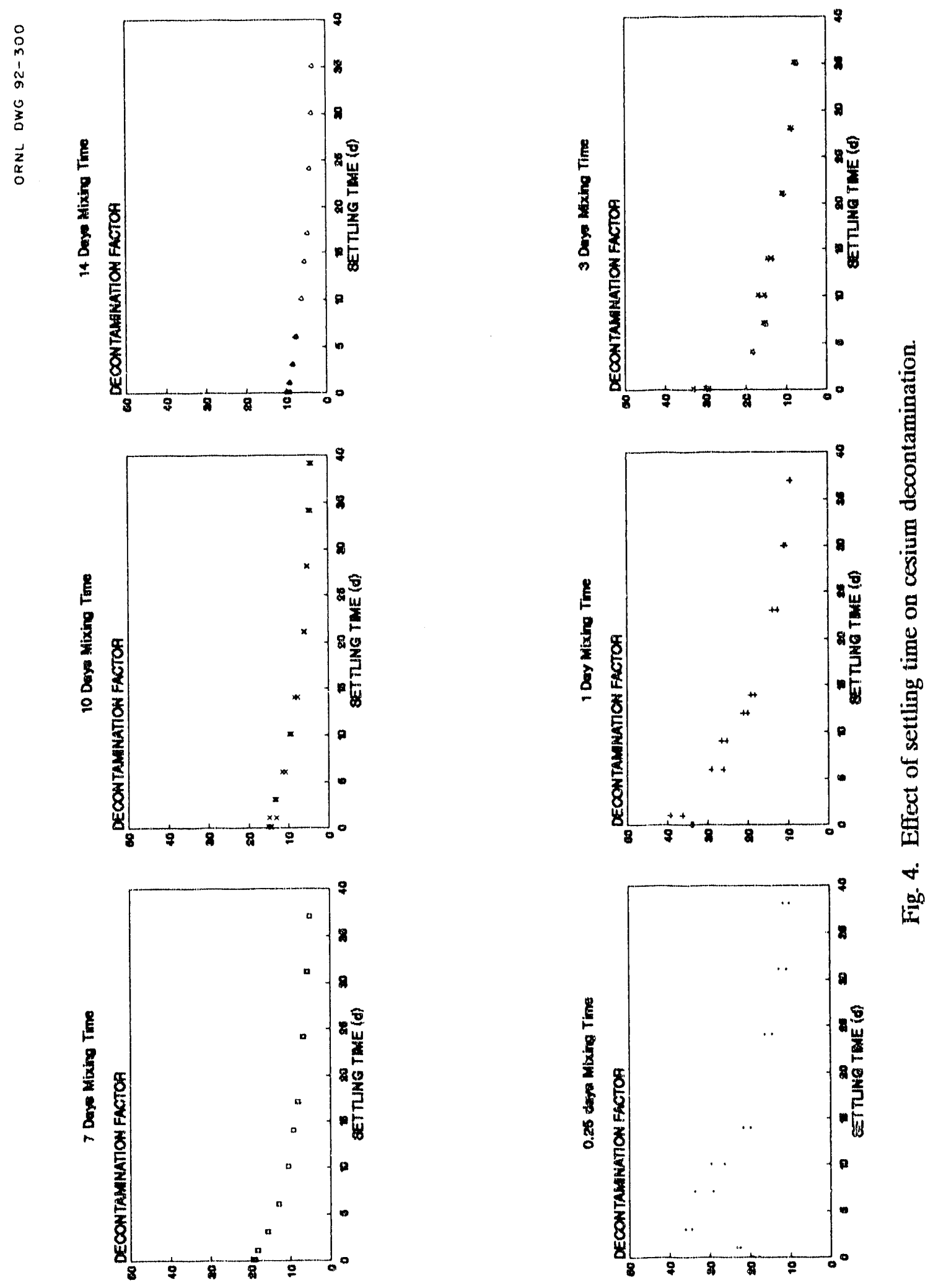
There does not appear to be any stratification of cesium in the tubes as the $\mathrm{KCCF}$ decomposes during settling (Fig. 5). Several samples, each containing $10 \mathrm{~mL}$ of simulated Tank 29 supernate and $0.01 \mathrm{~g} \mathrm{KCCF} \mathrm{sample} \mathrm{C,} \mathrm{were} \mathrm{mixed} \mathrm{for} 1 \mathrm{~d}$ and then allowed to settle. Nine $1-\mathrm{mL}$ aliquots and one $0.5-\mathrm{mL}$ aliquot were removed from the tube with the pipette tip just underneath the surface of the liquid. These samples were counted to determine whether there was a cesium concentration gradient in the mixing tube. The last sample $(0.5 \mathrm{~mL})$ was mixed with $0.5 \mathrm{~mL}$ of untraced supernate to maintain consistent counting geometry and the count rate was adjusted to compensate for the smaller sample size. The count rates did not show any variation that indicates stratification, and the results confirmed the decrease in DF with increasing settling time described above.

Design of a contactor for the particles and the supernate requires some knowledge of the particle characteristies (i.e., the particle shape and density). Immersion of a large particle of KCCF in water gave a density of about $2.3 \mathrm{~g} / \mathrm{cm}^{3}$, but also revealed that the particle was quite porous. In settling, the particle would carry with it the liquid in its pores and would have an effectively lower density. Haider and Levenspiel have developed a correlation accounting for the effect of particle shape on drag coefficients for single free-lalling particles."

Commercial KCCF sample A was screened to obtain fractions between sereen numbers 20 and 25 , and between numbers 50 and 60 . This yielded (wo batches of particles with average diameters of 774 and $273 \mu \mathrm{m}$. Settling tests were carried out in a 50()$-\mathrm{mL}$ cylinder with two liquids, water and simulated supernate. The density of the supernate was $1.37 \mathrm{~g} / \mathrm{mL}$. Tests were made with very small batches of particles (less than ten each), so that the hindered settling regime was avoided. Four to six replicate tests were made for each case. Precision was generally good, with maximum deviations from the average within $10 \%$. 
ORNI. OWO $92-301$

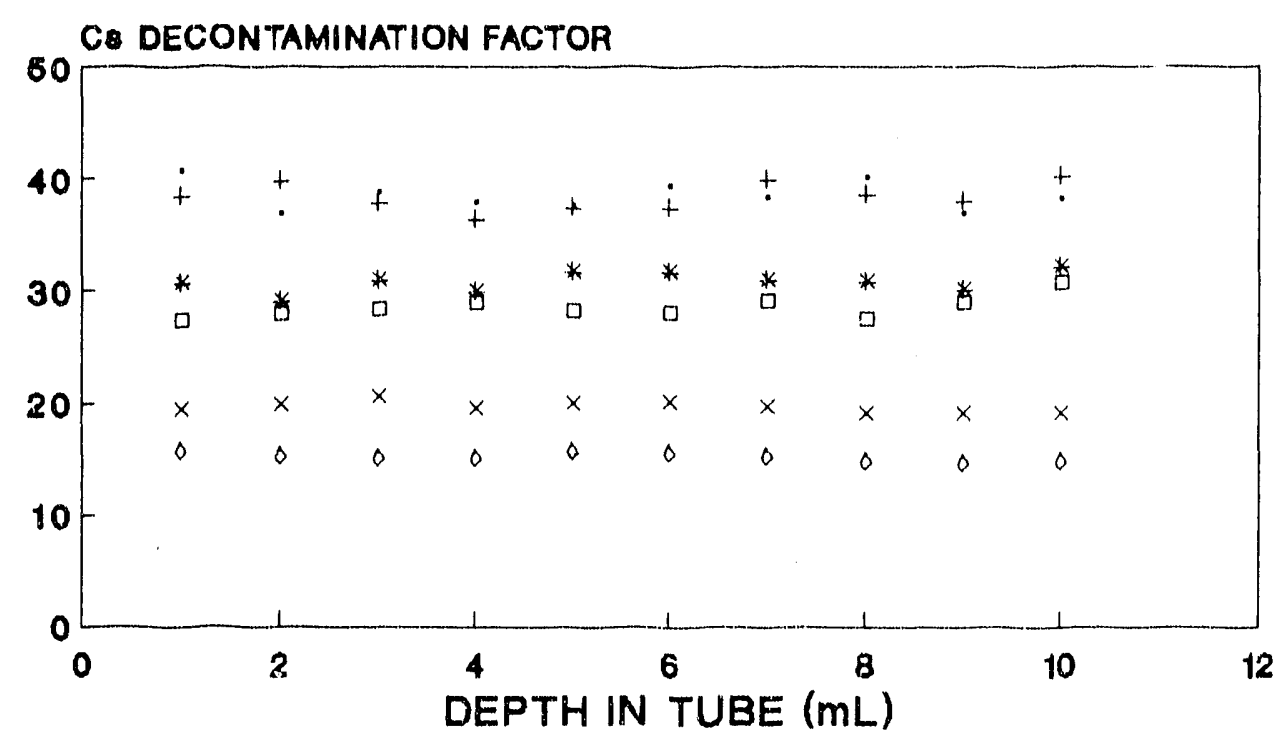

- $0.06 d+1 d * 4 d \quad \square d d 11 d \quad 016 d$

Fig. 5. Effect of sample location on cesium decontamination. 
The results are presented in Table: 4. Reynolds numbers were calculated from the experimental settling velocities. Drag coefficients were read from the correlation of Haider and Levenspiel. ${ }^{9}$ A sphericity of 0.8 was assumed initially on the basis that measured values for sand particles and pulverized coal dust ranged from 0.73 to $0.83 .{ }^{10}$ For Reynolds numbers lower than about 50, drag coetficients are not sensitive to sphericities between 0.7 to 1.0 , which covers particles that are not needle- or disc-shaped. Thus particle shape is not an important variable for this process. Valuci for the effective solid density ranged from 1.47 to 1.52 , with an average value of 1.49 .

Table 4. Results of settling tests

\begin{tabular}{|c|c|c|c|c|c|}
\hline $\begin{array}{l}\text { Particle } \\
\text { Diameter }\end{array}$ & Fluid & Velocity & $\begin{array}{l}\text { Reynolds } \\
\text { number }\end{array}$ & $\begin{array}{l}\text { Dray } \\
\text { coeff. }\end{array}$ & $\begin{array}{l}\text { Effective } \\
\text { density }\end{array}$ \\
\hline microns & & $\mathrm{lt} / \mathrm{sec}$ & & & $\mathrm{gm} / \mathrm{cm}$ \\
\hline 774 & water & 0.1600 & 36.3 & 2.00 & 1.47 \\
\hline 774 & supernate & 0.0570 & 17.7 & $3 .(0)$ & 1.49 \\
\hline 273 & water & 0.0484 & 3.88 & 8.50 & 1.52 \\
\hline \multirow[t]{2}{*}{273} & supern. & 0.0126 & 1.40 & 22.0 & 1.49 \\
\hline & & & & \multicolumn{2}{|c|}{ average $=1.49$} \\
\hline
\end{tabular}

\section{CONCLUSIONS AND RECOMMENDATIONS}

Test results indicate that under certain circumstances MVST supernate could be decontaminated using KCCF and solidified in concrete to produce a Class L-II waste form. However, the decontamination cannot be performed in situ by adding KCCF to the lanks prior to a solidification campaign. The reasons for this conclusion are:

1. There is a relatively short time limit for removing the treated supernates from the tanks. The KCCF begins to decompose after only a few days in :ontact with solutions at pH 13. The KCCF would lose most or all of its effectiveness in the time needed to remove the 
treated solution from the storage tanks. Kemoval of treated supernate from a storage tank in a solidification campaign might take as long as $90 \mathrm{~d} .{ }^{11}$ It is not feasible to adjust the pH of the supernates in the storage tanks in order to increase the cesium decontamination or the KCCF stability because of the pcssibility of dissolving part of the sludge in the tanks, which, in many cases, contains transuranic (TRU) wastes. Because the sludges are considerably more radioactive than the supernates, assurance would be needed before the supernate could be removed from the tank that any of the sludge that became suspended in the supernate during mixing with KCCF had settled. It is likely that the time required for the sludge to settle adequately would be longer than the time the KCCF eould retain the cesium.

2. In-tank treatment with KCCF is not permanent. Since the KCCF decomposes while in contact with strongly alkaline solutions and releases the cesium back into solution, the cesium would remain in the tank in soluble form and would require additional treatment in the future. The KCCF residue would also remain in the tank and could complicate furure operations $t$ treat the sludge for ultimate disposal.

Decontamination of the supernates should be possible if they are removed from the tanks and treated under more controlled conditions than is possible in the tanks. The envisioned treatment would include $\mathrm{pH}$ adjustment to an optimum range and batch treatment with KCCF in a stirred tank to remove the cesium from the solution, followed by separation of the solids by filtration or other means, and proper disposal of the treated liquid and the KCCF solids. Cesium sorption with KCCF has bee.l shown in other studies to be more effective at lower $\mathrm{pH},{ }^{7}$ and significantly smaller amounts of KCCF would likely be required. The $\mathrm{pH}$ could be adjusted outside the storage tank, avoiding the risk of dissolving any of the sludge. Unit operations such as filtration would be more effective than settling, which is the only phase separation option available for treatment in the storage tanks. Treatment at a 
lower $\mathrm{pH}$ could produce a inore stable final product in a smaller volume for ultimate disposal. The greater stability of the Cs-KCCF complex at lower $\mathrm{pH}$ would also increase the time available for separation and disposal of the treated supernate.

Significant development work is needed before tieatment of supernate could be implemented. Studies are needed to work out methods to: (1) prepare (or obtain) KCCF that is dependably effective, (2) determine the optimum $\mathrm{pH}$ range for cesium removal and the amounts of KCCF needed for adequate removal of eesium from the supernates, (3) determine the stability of the Cs-KCCF complex, (4) deveiop methods for separating the solids from the treated solution, and (5) determine some of the properties and ultimate disposal options for both the solids and treated liquids. Scaleup studies will also be needed to determine the effects on cesium decontamination of variables such as particle size, mixing time, and power input to the mixer. The storage tanks contain solutions with higher ${ }^{14} \mathrm{C}$ concentration than is allowable by Class L-II limits. Methods to reduce these concentrations to allowable limits will be needed in addition to the eesium deeontamination methods. 


\section{REFERENCES}

1. J. B. Berry et al, Process Development for Remote-Handled Mixed-Waste Treatment, presented at 1990 AIChE Summer National Meeting, San Diego, CA, August 1990.

2. D. O. Campbell, D. D. Lee, and T. A. Dillow, "Low-Level Waste Decontamination by Ion Exchange," Waste Management 1990, pp. 389.398 in Proceedings of the Symposium on Waste Management, Tucson, AZ, February 1990.

3. I. E. McNeese, et al., Overall Strategy and Program Plan for Management of Radioactively Contaminated Liquid Waste and Transuranic Sludge at the Oak Ridge National Laboratory, ORNL/TM-10757, Martin Marietta Energy Systerns, Inc., Oak Ridge National Laboratory, December 1988.

4. T. E. Myrick, et al., The Emergency Avoidance Solidification Campaign of Liquid LowLevel Waste at Oak Ridge National Laboratory, ORNL. TM-11536 in publication.

5. M. B. Sears, et al., Sampling and Analysis of Radioactive Liquid Wastes and Sludge in the Melton Valley and Evaporator Facility Storage Tanks at ORNL, ORNL/TM-11652, Martin Marietta Energy Systems, Inc., Oak Ridge National Laboratory, September 1990.

6. Jeff Baldwin, Oak Ridge National Laboratory, Oak Ridge, TN, personal communication to S. M. Robinson, Oak Ridge National Laboratory, Oak Ridge, TN, December 1990.

7. D. O. Campbell, D. D. Lee, and T. A. Dillow, Development Studies for Treatment of Low-Level Liquid Waste, ORNL/TM-11798, Martin Marietta Energy Systems, Inc., Oak Ridge National Laboratory, November 1991.

8. W. E. Prout, E. R. Russell, and H. J. Grch, "Ion Exchange Absorption of Cesium by Potassium Hexacyone Cobalt (11) Ferrate (II), "J. Inorg. Nucl. Chem., 27, 473-479, 1965.

9. A Haider and O. Levenspiel, "Drag Coefficient and Terminal Velocity of Spherical and Nonspherical particles," Powder Technol., 58, 63-70 (1989).

10. W. L. McCabe, J. C. Smith, and P. Harriott, Unit Operations of Chemical Engineering, McGraw-Hill, New York, 1985.

11. Robyn Srchultz, Oak Ridge National Laboratory, Oak Ridge, T'N, personal communication to S. M. Robinson, Oak Ridge National Laboratory, Oak Ridge, TN, March 1991. 
ORNL/TM-12031

\section{INTERNAL DISTRIBUTION}

1-10. W. D. Arnold

11. P. L. Askew

12. J. W. Autry 13. P. T. Barton

14. J. M. Begovich

15. J. T. Bell

16. C. E. Benson

17. S. E. Breeding

18. C. H. Brown

19. J. M. Brown

20. B. S. Bowers

21. C. H. Byers

22. C. Clark, Jr.

23. J. L. Collins

24. D. A. Conatser

25. A. G. Croff

26. D. J. Davidson

27. J. S. Davidson

28. D. L. Daugherty

29. S. M. DePaoli

30. B. G. Eads

31. B. Z. Egan

32. C. A. Easterday

33. J. T. Etheridge

34. L. M. Ferris

35. J. R. Forgy, Jr.

36-45. V. L. Fowler

46. C. E. Frye

47. W. Fulkerson

48. K. V. Gabrielsen

49. H. R. Gaddis

50. S. B. Garland

51. R. K. Genung

52. R. G. Grubb

53. R. E. Helms

54. J. R. Hightower

55. F. R. Hodges

56. D. W. Holladay

57. J. H. Hooyman

58. R. J. Hydzik

59. C. M. Kendrick

60. T. E. Kent

61-63. K.H. King-Jones
64. F. C. Kornegay

65. J. R. Lawson

66. R. Macon

67. J. L. Maddox

68. C. P. Manrod

69. R. C. Mason

70. R. F. Masterson

71. B. C. McClelland

72. L. E. McNeese

73-82. D. R. McTaggart

83. S. R. Michaud

84. T. H. Monk

85. C. E. Nix

86. R. C. Orrin

87. J. R. Parrott, Jr.

88. B. D. Patton

89-98. J. J. Perona

99. D. I. Peterson

100. S. M. Robinson

101. P. H. Roush

102. S. T. Rudell

103. T. F. Scanlar.

104. C. B. Scott

105. J. A. Setaro

106. R. B. Shelton

107. G. W. Sherrill

108. L. R. Simmons

109. J. L. Snyder

110. M. G. Stewart

111. R. C. Stewart

112. L. E. Stratton

113. J. H. Swanks

114. W. T. Thompson

115. J. R. Trabalka

116. J. R. Travis

117. M. W. Tull

118. D. W. Turner

119. C. K. Valentine

120. R. I. Van Hook

121. A. B. Walker

122. D.M. Wasserman

123. J. S. West

124. W. C. Yee
125. D. S. Zill

127. Central Research Library

128. Document Reference Section

129-130. Laboratory Records

131. Laboratory Records, R.C.

132. ORNL Patent Section 


\section{EXTERNAL DISTRIBUTION}

133. Office of Assistant Manager, Energy Research and Development, DOE-OR, P.O. Box 2001, Oak Ridge, TN 37831

134-143. Office of Scientific and Technical Information, P. O. Box 62, Oak Ridge, TN 37831 
